\title{
PENERAPAN MODEL PEMBELAJARAN INQUIRI UNTUK MENINGKATKAN HASIL BELAJAR SISWA KELAS X PADA MATA PELAJARAN DASAR AKUNTANSI DI SMKN 4 KOTA SERANG
}

\author{
Nely Hartika ${ }^{1)}$,Ira Ismeylia Saputri ${ }^{2)}$ \\ Universitas Banten Jaya \\ Serang, Indonesia \\ nelyhartika@unbaja.ac.id,iraismeyliasaputri@ unbaja.ac.id
}

\begin{abstract}
This study aims to find out how the application of inquiry learning models in accounting subjects in class X AK in SMKN 4 Serang City and to find out whether the inquiry learning model can improve student learning outcomes in class X AK in Accounting Basic Subjects in SMK 4 Serang City.This research uses a class action research method which consists of two cycles. Each cycle consists of four stages, namely planning, implementing, observing reflection. The subjects of this study were participants in grade X SMK 4 Serang City consisting of 36 students and teachers in Accounting as a team of collaborators. These results indicate that the Inquiry learning model can improve student learning outcomes based on cycle one, from 36 students who succeeded in getting grades above the KKM of $36.56 \%$ with an average value of 66, whereas in the second cycle there was a significant increase to be $100 \%$ with an average value of 82 .
\end{abstract}

Keywords : Learning Model, Inquiry, Learning Outcomes

\section{PENDAHULUAN}

Pendidikan nasional dewasa ini sedang diharapkan pada empat krisis pokok, yang berkaitan dengan kuantitas, relevansi atau efesiensi eksternal, elitisme dan manajemen.Sedikitnya ada tujuh masalah pokok sistem pendidikan nasional seperti; menurunnya akhlak dan moral peserta didik, pemerataan kesempatan belajar, masih rendahnya efesiensi internal sistem pendidikan, status kelembagaan, manajemen pendidikan yang tidak sejalan, pembangunan nasional yang tidak sejalan dan sumber daya yang belum sesuai dengan bidangnya.

$$
\text { Berdasarkan pengamatan di }
$$
sekolah, terlihat bahwa dalam proses pembelajaran Dasar Akuntansi di SMKN 4 Kota Serang Kelas X masih sering dijumpai adanya kecenderungan siswa yang tidak mau bertanya kepada guru meskipun sebenarnya belum mengerti tentang materi yang disampaikan. Tetapi ketika guru menanyakan bagianmana yang belum dimengerti seringkali siswa hanya diam, dan setelah guru memberikan soal latihan 
barulah guru mengerti bahwa sebenarnya ada bagian dari materi yang belum di mengerti siswa. Proses pembelajaran Akuntansi di SMKN 4 Kota Serang Kelas $\mathrm{X}$ masih didominasi oleh guru sehingga keaktifan siswa dalam kelas masih kurang dan tidak sempat mendorong siswanya untuk kreatif dan berpikir kritis dalam mengembangkan kemampuannya dalam setiap tatap muka. Selain itu mata pelajaran Dasar Akuntansi adalah salah satu mata pelajaran yang menjadi momok dan membuat siswa sangat merasa jenuh.disamping itu guru hanya menggunakan metode konvensional dan ceramah sehingga membuat siswa menjadi cepat bosan sehingga hasil belajar siswa sangat rendah. Dengan demikian diharapkan model pembelajaran Inquiri dapat menyelesaikan masalah sehingga siswa dapat termotivasi dalam proses pembelajaran dan meningkatnya hasil belajar siswa.

Menghadapi hal tersebut, perlu dilakukan penataan terhadap sistem pendidikan secara kaffah (menyeluruh), terutama berkaitan dengan kualitas pendidikan dan proses pembelajaran yang lebih baik, serta relevansinya dengan kebutuhan masyarakat dan dunia kerja. Dalam hal ini, perlu adanya perubahan sosial pendidikan dalam model pembelajaran yang memberi arah bahwa pendidikan adalah merupakan pendekatan dasar dalam proses perubahan itu, pendidikan adalah kehidupan, untuk itu kegiatan belajar harus dapat membekali peserta didik dengan kecakapan hidup (life skill atau life competency) yang sesuai dengan lingkungan kehidupan dan kebutuhan peserta didik.

Pembelajaran dapat dikatakan sebagai hasil memori, kognisi dan metakognisi yang berpengaruh terhadap pemahaman. Hal inilah yang sering terjadi ketika seseorang sedang belajar, dan kognisi juga sering terjadi dalam kehidupan sehari-hari, karena belajar merupakan proses alamiah setiap orang. Menurut Wenger dalam Huda (2014:2) menyatakan bahwa

"pembelajaran bukanlah aktivitas, sesuatu yang dilakukan oleh seseorang ketika ia tidak melakukan aktivitas yang lain. Pembelajaran juga bukanlah sesuatu yang berhenti dilakukan oleh seseorang. Lebih dari itu, pembelajaran bisa terjadi di mana saja dan pada level yang berbeda-beda, secara individu, kolektif, ataupun sosial."

Dalam merancang pengalaman belajar, seorang guru harus mampu menciptakan metode-metode pengajaran yang efektif bagi siswa sehingga guru dapat mendorong siswa dengan model dan 
pembelajarannya sebagai upaya pengembangan anak didik seutuhnya.

Agar pengajaran menjadi lebih efektif dan afektif, pembelajar seharusnya dipahami lebih dari sekedar penerima pasif pengetahuan, melainkan seseorang yang secara aktif terlibat dalam proses pembelajaran yang diarahkan oleh guru menuju lingkungan kelas yang nyaman dan kondisi emosional, sosiologis, psikologis dan fisiologis yang kundusif (Dunn dan Dunn 1992) dalam Huda (2014:2).

Kegiatan belajar mengajar di kelas merupakan proses interaksi antara guru dan siswa dalam lingkungan pendidikan. Proses belajar mengajar mempunyai tujuan yang harus dicapai oleh siswa setelah proses belajar mengajar berlangsung. Faktor-faktor yang mempengaruhi tercapainya tujuan mengajar adalah materi, metode dan alat evaluasi. Berkaitan dengan hal di atas, maka harus diciptakan suasana belajar yang melibatkan siswa secara aktif dan bukan lagi guru yang mendominasi kegiatan ini. Jadi, dalam hal ini guru dituntut harus memiliki kemampuan menggunakan metode dan media pengajaran yang tepat sehingga dapat melibatkan siswa secara aktif dalam proses belajar mengajar dan materi yang disampaikan dapat dipahami siswa.

Ada beberapa model pengajaran dalam pembelajaran sains yaitu : pengajaran langsung (direct instruction), pembelajaran kooperatif ( cooperatif learning) dan pengajaran berdasarkan masalah (problem solving) serta pengajaran proses berpikir secara kritis (Inquiri.)Dari model-model pembelajaran tersebut, model pembelajaran inquiri merupakan model yang diterapkan dalam penelitian ini. Metode pembelajaran Inkuiri merupakan rangkaian kegiatan pembelajaran yang menekankan pada proses berfikir kritis dan analitis untuk mencari dan menemukan jawaban dari suatu masalah. Proses berpikir biasanya dilakukan melalui Tanya jawab antara guru dan siswa. Strategi pembelajaran ini sering juga dinamakan strategi heuristic, yang berasal dari bahasa Yunani, yaitu heuriskein yang berarti saya menemukan.

\section{Model}

pembelajaran

inquiridiharapkan dapat memberikan perubahan dalam proses pembelajaran pada siswa kelas X SMKN 4 Kota Serang pada Mata Pelajaran Dasar Akuntansi yang saat ini nilai hasil belajarnya masih harus ditingkatkan, karena salah satu tujuan dalam pembelajaran diantaranya yaitu berhubungan dengan hasil belajar siswa, pembelajaran inquiri juga dapat membantu mengembangkan pengetahuan dan melatih berpikir kritis diantara siswa.

Berdasarkan uraian di atas peneliti merasa tertarik untuk mengetahui 
penerapanmodel pembelajaran inquiriuntuk meningkatkan hasil belajar siswa kelas $\mathrm{X}$ pada Mata Pelajaran Dasar Akutansi.di SMKN 4 Kota Serang.

Menurut Dewey dalam Joyce dan Weil (1986) dalam Majid (2016:13) mendefinisikan model pembelajaran sebagai suatu rencana atau pola yang dapat kita gunakan untuk merancang tatap muka dikelas dan untuk menajamkan materi pengajaran).

Sedangkan menurut Arends (1997) dalam Majid (2016:13) mengemukakan bahwa model pengajaran mengarah pada suatu pendekatan pembelajaran tertentu termasuk tujuannya, sintaksnya, lingkungan dan system pengelolaannya.

Dari beberapa pengertian tentang model pembelajaran tersebut diatas dapat dipahami dan disimpulkan bahwa model pembelajaran merupakan kerangka dasar pembelajaran yang dapat diisi oleh beragam muatan mata pelajaran, sesuai dengan karakteristik kerangka dasarnya.Model pembelajaran dapat muncul dalam beragam bentuk dan variasinya seseuai dengan landasan filosofis dan pedagogis yang melatar belakanginya.

Adapun beberapa pengertian mengenai ModelPembelajaran Inkuiri menurut para ahli sebagai berikut:
Majid (2016:222) mengemukakan "pembelajaran inkuiri merupakan rangkaian kegiatan pembelajaran yang menekankan pada proses berpikir kritis dan analitis untuk mencari dan menemukan sendiri jawaban dari suatu masalah yang dipertanyakan".

Sagala (2011:196), Metode inkuiri merupakan metode pembelajaran yang berupaya menanamkan dasar-dasar berfikir ilmiah pada diri siswa yang berperan sebagai subjek belajar, sehingga dalam proses pembelajaran ini siswa lebih banyak belajar sendiri, mengembangkan kreativitas dalam memecahkan masalah.

1. Ciri-ciri Strategi Inquiri

Ada beberapa hal yang menjadi ciri utama model pembelajaran inkuiri yang menurut Majid (2016: 222) adalah strategi pembelajaran inkuiri yang meliputi:

a) Strategi inkuiri menekankan kepada aktivitas siswa secara maksimal untuk mencari dan menemukan, artinya strategi inkuiri menempatkan siswa sebagai subjek belajar. Dalam proses pembelajaran, siswa tidak hanya berperan sebagai penerima pelajaran melalui penjelasan guru secara verbal, tetapi mereka berperan untuk menemukan sendiri inti dari materi pelajaran itu sendiri.

b) Seluruh aktivitas yang dilakukan siswa diarahkan untuk mencari dan 
menemukan jawaban sendiri dari sesuatu yang ditanyakan, sehingga diharapkan dapat menumbuhkan sikap percaya diri (self belief). Dengan demikian, strategi pembelajaran inkuiri menempatkan guru bukan sebagai sumber belajar, akan tetapi sebagai fasilitator dan motivator belajar siswa. Aktivitas pembelajaran biasanya dilakukan melalui proses Tanya jawab antara guru dan siswa. Oleh sebab itu, kemampuan guru dalam menggunakan tekhnik bertanya merupakan syarat utama dalam melakukan inkuiri.

c) Tujuan dari penggunaan strategi pembelajaran inkuiri adalah mengembangkan kemampuan berfikir secara sistematis, logis, dan kritis, atau mengembangkan kemampuan intelektual sebagai bagian dari proses mental. Dengan demikian, dalam strategi pembelajaran inkuiri siswa tak hanya dituntut agar menguasai materi pelajaran, akan tetapi bagaimana mereka dapat menggunakan potensi yang dimilikinya. Manusia yang hanya menguasai pelajaran belum tentu dapat mengembangkan kemampuan berfikir secara optimal, namun sebaliknya siswa akan dapat mengembangkan kemampuan berfikirnya manakala ia bisa menguasai materi pelajaran.
Menurut Majid (2016:222), model pembelajaran Inkuiri adalah strategi pembelajaran inkuiri, yakni rangkaian kegiatan pembelajaran yang menekankan pada proses berfikir secara kritis dan analitis untuk mencari dan menemukan sendiri jawaban dari suatu masalah yang dipertanyakan. Strategi pembelajaran ini sering juga dinamakan strategi heuristic, yang berasal dari bahasa Yunani, yaitu heuriskein yang berarti saya menemukan.

Strategi Pembelajaran Inkuiri (SPI) berasal dari asumsi bahwa manusia lahir di dunia memiliki dorongan untuk menemukan pengetahuannya sendiri. Rasa ingin tahu tentang keadaan alam disekelilingnya merupakan kodrat manusia sejak ia lahir ke dunia. Sejak kecil manusia memiliki keinginan untuk mengenal segala sesuatu melalui indera pengecapan, pendengaran, penglihatan, dan inderaindera lainnya. Hingga dewasa keingintahuan manusia secara terusmenerus berkembang dengan menggunakan otak dan pikirannya. Pengetahuan yang dimiki manusia akan bermakna (meaningfull) manakala didasari oleh keingintahuan itu. Dalam rangka itulah strategi inkuiri dikembangkan.

Model pembelajaran inkuiri yang disebut Strategi pembelajaran inkuiri merupakan bentuk dari pendekatan pembelajaran yang berorientasi kepada 
siswa (student centered approach). student centered approach meletakkan siswa sebagai pemegang peran dominan pada kegiatan pembelajaran. Sanjaya (2016) mengatakan strategi pembelajaran inkuiri akan efektif manakala:

1. Guru mengaharapkan siswa dapat menemukan sendiri jawaban dari suatu permasalahan yang ingin dipecahkan. Dalam strategi inquiri penguasaan siswa terhadap materi pelajaran bukanlah tujuan utama kegiatan pembelajaran, tetapi lebih mementingkan pada proses belajar.

2. Jika bahan pelajaran yang akan diajarkan tidak berbentuk fakta atau konsep yang sudah jadi, akan tetapi sebuah kesimpulan yang perlu pembuktian.

3. Jika proses pembelajaran berangkat dari rasa ingin tahu siswa terhadap sesuatu.

4. Jika guru akan mengajar pada sekelompok siswa yang rata-rata memiliki kemauan dan kemampuan berpikir. Strategi inkuiri akan kurang berhasil diterapkan kepada siswa yang kurang memiliki kemampuan untuk berpikir.

5. Jika jumlah siswa yang belajar tak terlalu banyak sehingga bisa dikendalikan oleh guru.
6. Jika guru memiliki waktu yang cukup untuk mengguanakan pendekatan yang berpusat pada siswa.

2. Langkah Pelaksanaan Model Pembelajaran Inkuiri (SPI)

Secara umum Majid (2016: 225) mengemukakan bahwa proses pembelajaran dengan mengguanakan strategi pembelajaran inkuiri dapat mengikuti langkah-langkah sebagai berikut:

\section{a. Orientasi}

Langkah orientasi merupakan langkah untuk membina suasana atau iklim pembelajaran yang responsive. Pada langkah ini guru mengondisikan agar siswa siap melaksanakan proses pembelajaran. Langkah orientasi merupakan langkah yang sangat penting. Keberhasilan stratgi pembelajaran inkuiri sangat tergantung pada kemauan siswa untuk beraktivitas menggunakan kemampuannya dalam memecahkan masalah; tanpa kemauan dan kemampuan itu tak mungkin proses pembelajaran akan berjalan dengan lancar. Beberapa hal yang dapat dilakukan dalam tahapan orientasi ini adalah

1) Menjelaskan topik, tujuan, dan hasil belajar yang diharapkan dapat dicapai oleh siswa.

2) Menjelaskan pokok-pokok kegiatan yang harus dilakukan oleh siswa untuk mencapai tujuan.pada tahap ini guru menjelaskan langkah inquiri serta 
tujuannya dimulai dari merumuskan masalah sampai merumuskan kesimpulan

3) Menjelaskan pentingnya materi pembelajaran dan kegiatan belajar sehingga siswa akan memiliki motivasi.

b. Merumuskan Masalah

Merumuskan masalah merupakan langkah membawa siswa pada suatu persoalan yang mengandung teka-teki. Persoalan yang disajikan adalah persoalan yang menantang siswa untuk berpikir memecahkan teka teki itu. Dikatakan teka teki dalam rumusan masalah yang ingin dikaji disebabkan masalah itu tentu ada jawabannya dan siswa didorong untuk mencari jawaban yang tepat. Proses mencari jawaban sangat penting dalam strategi inquiri karena siswa akan memperoleh pengalaman berharga sebagai upaya pengembangan mental melalui berfikir. Dengan demikian, teka teki yang menjadi masalah dalam berinkuiri adalah teka teki yang mengandung konsep yang jelas yang harus dicari dan ditemukan. Ini penting dalam pembelajaran inkuiri. Beberapa halyang harus diperhatikan dalam merumuskan masalah, diantaranya:

1) Masalah hendaknya dirumuskan sendiri oleh siswa. Ketika siswa terlibat dalam kegiatan perumusan masalah siswa akan memiliki motivasi belajar yang tinggi Dengan demikian, guru sebaiknya tidak merumuskan sendiri masalah pembelajaran, guru hanya memberikan topik yang akan dipelajari, sedangkan bagaimana rumusan masalah yang sesuai dengan topik yang telah ditentukan sebaiknya diserahkan kepada siswa.

2) Masalah yang dikaji adalah masalah yang mengandung teka teki yang jawabannya pasti. Artinya guru dapat mendorong agar siswa dapat merumuskan masalah yang menurut guru jawaban sebenarnya sudah ada, tinggal siswa mencari dan mendapatkan jawabannya secara pasti.

3) Konsep-konsep dalam masalah adalah konsep-konsep yang sudah diketahui terlebih dahulu oleh siswa. Guru harus yakin bahwasiswa telah memiliki pemahaman mengenai konsep dalam rumusan masalah sebelum dikasi melalui proses inquiri. Jangan harapkan siswa dapat melakukan tahapan inkuiri selanjutnya, manakalaia belum paham konsep-konsep yang terkandung dalam rumusan masalah.

\section{c. Merumuskan Hipotesis}

Hipotesis merupakan jawaban sementara dari suatu permasalahan yang sedang dikaji. Sebagai jawaban sementara, hipotesis perlu diuji kebenarannya. Kemampuan atau potensi individu untuk berpikir pada dasarnya sudah dimiliki sejak 
individu itu lahir. Potensi berpikir tersebut dimulai dari kemampuan setiap individu untuk menebak atau mengira-ngira (berhipotesis) dari suatu permasalahan. Manakala individu dapat membuktikan tebakannya, maka ia akan sampai pada posisi yang bisa mendorong untuk berpikir lebih lanjut. Oleh sebab itu, potensi untuk mengembangkan kemampuan menebak pada setiap individu harus dibina. Salah satu cara yang dapat dilakukan guru untuk mengembangkan kemampuan menebak (berhipotesis) pada setiap anak adalah dengan mengajukan berbagai pertanyaan yang dapat mendorong siswa untuk dapat merumuskan jawaban sementara atau dapat merumuskan berbagai perkiraan kemungkinan jawaban dari suatu permasalahan yang dikaji. Perkiraan sebagai hipotesis bukan sembarang perkiraan, tetapi harus memiliki landasan berpikir yang kokoh, sehingga hipotesis yang dimunculkan itu bersifat rasional dan logis. Kemampuan berpikir logis itu sendiri akan sangat berpengaruh oleh kedalaman wawasan yang dimiliki serta keluasan pengalaman.

d. Mengumpulkan Data

Mengumpulkan data adalah aktivitas memperoleh informasi untuk menguji hipotesis. Dalam strategi pembelajaran inkuiri, mengumpulkan data merupakan proses mental yang sangat penting dalam pengembangan intelektual. Proses pengumpulan data bukan hanya memerlukan motivasi yang kuat dalam belajar, akan tetapi juga membutuhkan ketekunan dan kemampuan menggunakan potensi berpikirnya. Oleh sebab itu, tugas dan peran guru dalam tahapan ini adalah mengajukan pertanyaan-pertanyaan yang dapat mendorong siswa untuk berpikir mencari informasi yang dibutuhkan. Manakala guru menemukan gejala-gejala semacam ini, maka guru hendaknya secara terus menerus memberikan dorongan kepada siswa untuk belajar melalui penyuguhan berbagai jenis pertanyaan secara merata kepada seluruh siswa sehingga meraka terangsang untuk berpikir.

\section{e. Menguji Hipotesis \\ Menguji hipotesis merupakan proses} penentuan jawaban yang dianggap diterima sesuai dengan data dan informasi yang diperoleh. Yang terpenting dalam menguji hipotesis adalah mencari tingkat keyakinan siswa atau jawaban yang diberikan. Disamping itu, menguji hipotesis juga berarti mengembangkan kemampuan berikir rasional. Artinya, kebenaran jawaban yang diberikan bukan hanya berdasarkan argumentasi, akan tetapi harus didukung oleh data yang ditemukan dan dapat dipertanggung jawabkan. 


\section{f. Merumuskan Kesimpulan}

Merumuskan kesimpulan merupakan proses mendeskripsikan temuan yang diperoleh berdasarkan hasil pengujian hipotesis. Merumukan kesimpulan merupakan gong-nya dalam proses pembelajaran. Sering terjadi karena banyaknya data yang diperoleh, menyebabkan kesimpulan yang dirumuskan tidak fokus terhadap masalah yang hendak dipecahkan. Untuk memperoleh kesimpulan yang akurat sebaiknya guru dapat menunjukkan data yang relevan kepada siswa.

Selanjutnya ada tiga karakteristik pengembangan strategi inkuiri social. Pertama, adanya aspek (masalah) sosial dalam kelas yang dianggap penting dan dapat mendorong terciptanya diskusi kelas. Kedua, adanya rumusan hipotesis sebagai fokus untuk inkuiri. Ketiga, penggunaan fakta sebagai pengujian hipotesis. Dari karakteristik inkuiri seperti telah diuraikan diatas, maka tampak inkuiri social pada dasarnya tidak berbeda dengan inkuiri pada umumnya. Perbedaannya terletak pada masalah yang dikaji adalah masalahmasalah social atau masalah kehidupan masyarakat.
4. Keunggulan dan Kelemahan Metode Pembelajaran Inkuiri

Pada penerapannya metode pembelajaran inquiri memiliki keunggulan dan kelemahan antara lain:

\section{a. Keunggulan \\ Keunggulan metode pembelajaran} inkuiri yang diungkap Majid (2016:227) ialah strategi pembelajaran inkuiri merupakan strategi pembelajaran yang banyak dianjurkan oleh karena strategi ini memiliki beberapa keunggulan, diantaranya:

1) Strategi pembelajaran inkuiri merupakan strategi pembelajaran yang menekankan pada pengembangan aspek kognitif, afektif, dan psikomotor secara seimbang, sehingga pembelajaran melalui strategi ini dianggap lebih bermakna.

2) Strategi pembelajaran inkuiri dapat memberikan ruang kepada siswa untuk belajar sesuai dengan gaya belajar mereka.

3) Strategi pembelajarn inkuiri merupakan strategi yang dianggap sesuai dengan perkembangan psikologi belajar modern yang menganggap belajar adalah proses perubahan tingkah laku berkat adanya pengalaman.

4) Keuntungan lain adalah strategi pembelajaran ini dapat melayani kebutuhan siswa yang memiliki 
kemampuan diatas rata-rata. Artinya, siswa yang memiliki kemampuan belajar bagus tidak akan terhambat oleh siswa yang lemah dalam belajar.

b. Kelemahan

Kelemahan metode pembelajaran inkuiri yang diungkap Majid, (2016: 227) menyatakan bahwa disamping memiliki keunggulan, strategi pembelajaran inkuiri mempunyai kelemahan, diantaranya:

1) Jika SPI digunakan sebagai strategi pembelajaran, maka akan sulit mengontrol kegiatan dan keberhasilan siswa.

2) Strategi ini sulit dalam merencanakan pembelajaran oleh karena terbentur dengan kebiasaan siswa dalam belajar.

3) Kadang-kadang dalam mengimplementasikannya, memerlukan waktu yang panjang sehingga sering guru sulit menyesuaikannya dengan waktu yang telah ditentukan.

4) Selama kriteria keberhasilan belajar ditentukan oleh kemampuan siswa menguasai materi pelajaran, maka strategi pembelajaran inkuiri akan sulit diimplementasikan oleh setiap guru.

Dari uraian diatas dapat penulis simpulkan bahwa model pembelajaran inquiri suatu model pembelajaran yang menekankan pada proses berfikir secara kritis dan analitis untuk mencari dan menemukan sendiri jawaban dari suatu masalah yang dipertanyakan, dengan demikian model ini mampu memotivasi siswa untuk menemukenali titik permasalahan. Strategi pembelajaran ini sering juga dinamakan strategi heuristic, yang berasal dari bahasa Yunani, yaitu heuriskein yang berarti saya menemukan.

Hasil belajar siswa pada hakekatnya adalah perubahan tingkah laku. Tingkah laku sebagai hasil belajar dalam pengertian yang luas mencakup bidang kognitif, afektif dan psikomotorik. Hasil belajar adalah suatu ukuran perubahan tingkah laku yang dicapai melalui belajar, sedangkan menurut Nasution memberikan definisi hasil belajar sebagai suatu perubahan pada individu yang belajar, perubahan ini tidak hanya mengenai pengetahuan saja tetapi juga membentuk kecakapan, sikap, pengertian, penguasaan, dan penghargaan dalam diri individu yang belajar.

Proses belajar mengajar merupakan inti dari proses pendidikan secara keseluruhan, dengan guru sebagai peran utamanya. Proses pendidikan yang efektif hendaknya ditunjang dengan administrasi yang memadai, sistem pengajaran yang efektif, kurikulum yang relevan, serta didukung dengan sistem pelayanan bimbingan yang terarah. 
Dalam proses belajar mengajar, guru mempunyai tugas untuk merangsang, membimbing dan memberikan fasilitas belajar bagi siswa, sehingga perkembangan dan hasil belajar siswa meningkat. Guru hendaknya mampu membantu setiap siswa menggunakan kesempatan belajar. Hal ini mengandung arti bahwa guru hendaknya dapat mengembangkan cara dan kebiasaan belajar yang sebaik-baiknya.

Belajar merupakan proses dalam diri individu yang berinteraksi dengan lingkungan untuk mendapatkan perubahan dalam perilakunya. Belajar adalah aktivitas mental/psikis yang berlangsung dalam interaksi aktif dengan lingkungan yang menhasilkan perubahan-perubahan dalam pengetahuan, keterampilan dan sikap (Winkel, 1999) dikutif dalam buku (Purwanto, 2016:39)

Penilaian hasil belajar merupakan rangkaian kegiatan untuk menentukan pencapaian kompetensi siswa terhadap suatu mata pelajaran. Penilaian memiliki beberapa manfaat dan memberikan umpan balik mengenai kemajuan belajar siswa. Selain itu, penilaian juga membantu guru untuk membuat keputusan-keputusan mengenai kebutuhan dan kemampuan siswa dan perencanaan program pembelajaran selanjutnya Majid, 2016:335).
Menurut Seriven dan Paul (dalam Suwarma, 2009:11), berpikir kritis merupakan sebuah proses intelektual dengan melakukan pembuatan konsep, penerapan, melakukan sintesis, dan atau mengevaluasi informasi yang diperoleh dari observasi, pengalaman, refleksi, pemikiran atau komunikasi sebagai dasar untuk meyakini dan melakukan suatu tindakan.

$$
\text { Sedangkan menurut Surya }
$$

(2011:131), berpikir kritis merupakan kegiatan yang aktif, gigih, dan pertimbangan yang cermat mengenai sebuah keyakinan atau bentuk pengetahuan apapun yang diterima dipandang dari berbagai sudut alasan yang mendukung dan menyimpulkan.

Sedangkan menurut Wijaya (2010:72), berpikir kritis yaitu kegiatan menganalisis ide atau gagasan ke arah yang lebih spesifik, membedakannya secara tajam, memilih, mengidentifikasi, mengkaji dan mengembangkannya ke arah yang lebih sempurna.

Dari beberapa pengertian diatas dapat disimpulkan bahwa berpikir kritis adalah sebuah proses kegiatan menganalisa yang terorganisir dan jelas yang digunakan dalam aktivitas mental seperti pemecahan masalah, pembuat keputusan, menganalisis asumsi-asumsi, dan penemuan secara ilmiah. 
Menurut Seifert dan Hoffnung (dalam Desmita, 2010:154), terdapat empat komponen berpikir kritis, yaitu sebagai berikut:

1. Basic operations of reasoning. Untuk berpikir secara kritis, seseorang memiliki kemampuan untuk menjelaskan, menggeneralisasi, menarik kesimpulan deduktif dan merumuskan langkah-langkah logis lainnya secara mental.

2. Domain-specific knowledge. Dalam menghadapi suatu problem, seseorang harus mengetahui tentang topik atau kontennya. Untuk memecahkan suatu konflik pribadi, seseorang harus memiliki pengetahuan tentang person dan dengan siapa yang memiliki konflik tersebut.

3. Metakognitive knowledge. Pemikiran kritis yang efektif mengharuskan seseorang untuk memonitor ketika ia mencoba untuk benar-benar memahami suatu ide, menyadari kapan ia memerlukan informasi baru dan mereka-reka bagaimana ia dapat dengan mudah mengumpulkan dan mempelajari informasi tersebut.

4. Values, beliefs and dispositions. Berpikir secara kritis berarti melakukan penilaian secara fair dan objektif. Ini berarti ada semacam keyakinan diri bahwa pemikiran benar-benar mengarah pada solusi. Ini juga berarti ada semacam disposisi yang persisten dan reflektif ketika berpikir.

\section{METODE PENELITIAN}

Setting Penelitian

Dalam penelitian ini digunakan pre test dan post test untuk mengukur perolehan pengetahuan siswa sebelum penerapan model pembelajaran dan sesudah penerapan model pembelajaran.

Desain Penelitian

Penelitian Tindakan Kelas ini dilaksanakan dalam 2 (dua) siklus, setiap siklus dilaksanakan dalam 4 (empat) tahap, yaitu :
a. Perencanaan tindakan
b. Pelaksanaan tindakan
c. Observasi
d. Refleksi tindakan.

Prosedur Penelitian

Prosedur penelitian dalam penelitian ini menggunakan Penelitian Tindakan Kelas (PTK) dilaksanakan melalui dua siklus untuk melihat peningkatan hasil belajar siswa pada mata pelajaran Dasar Akuntansi melalui penerapan model pembelajaran Inquiri. Tujuan PTK adalah meningkatkan atau memperbaiki praktik pembelajaran yang dilakukan oleh Guru. Tujuan diatas dapat tercapai dengan melakukan berbagai 
tindakan alternative dalam memecahkan persoalan pembelajaran dikelas.

Model penelitian yang diterapkan merupakan PenelitianTindakan Kelas (PTK) maka pelaksanannya dilakukan dengan cara bersiklus seperti gambar dibawah ini :

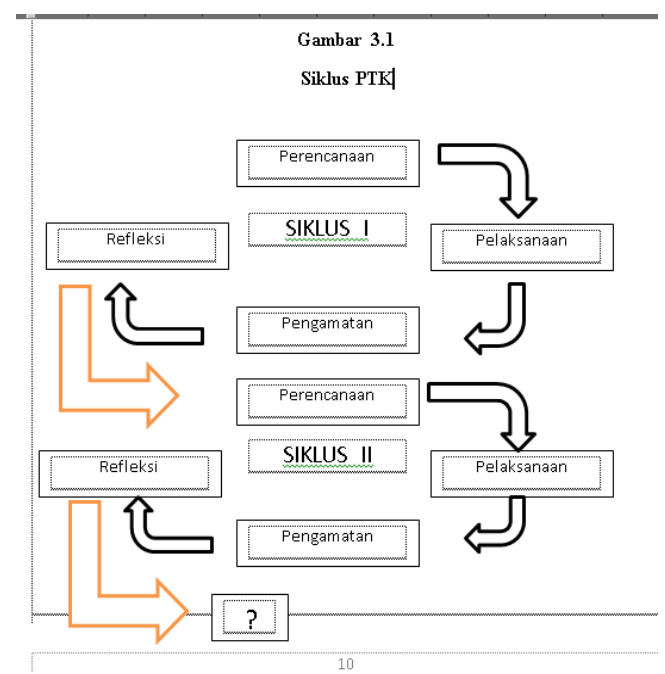

(Arikunto, 2015: 42)

\section{Siklus I}

a) Perencanaan Tindakan

1. Menyusun

perangkat pembelajaran berupa silabus dan RPP dan menyiapkan media yang akan digunakan.

2. Menyusun format observasi dan evaluasi pembelajaran

3. Menyusun skenario pelaksanaan tindakan

b) Pelaksanaan Tindakan

1. Menyiapkan siswa untuk menerima materi pelajaran

2. Mengelola kelas
3. Absensi kehadiran siswa

4. Menyampaikan tujuan pembelajaran dengan menggunakan model pembelajaran inquiri.

5. Menyajikan materi pelajaran

6. Memberikan kesempatan kepada siswa untuk bertanya

7. Melakukan umpan balik kepada siswa, siswa dibagi menjadi 6 kelompok.

8. Setiap kelompok menempati tempat duduknya secara kelompok

9. Guru menyiapkan wacana tentang materi Dasar Akuntansi

10. Guru memberikan soal yang telah diacak nomornya untuk dikerjakan siswa secara berkelompok, masing-masing kelompok soalnya berbeda.

11. Siswa dalam kelompok masingmasing mengerjakan soal sesuai dengan soal yang ada dalam kelompok

12. Setelah soal dikerjakan maka guru membuat kesimpulan

c) Tahap Observasi

Observasi dilakukan saat proses pembelajaran.

d) Tahap Refleksi

Kegiatan pada tahap ini adalah pencermatan, pengkajian, analisis, 
sintesis dan penilaian observasi terhadap tindakan yang telah dilakukan. Jika terdapat masalah dalam proses refleksi pada siklus I, maka dilakukan proses pengkajian ulang pada siklus berikutnya.

\section{Siklus II}

a) Perencanaan Tindakan

1. Menyusun perangkat pembelajaran berupa silabus dan RPP dan menyiapkan media yang akan digunakan.

2. Menyusun format observasi dan evaluasi pembelajaran.

3. Menyusun skenario pelaksanaan tindakan

b) Pelaksanaan Tindakan

1. Menyiapkan siswa untuk menerima materi pelajaran

2. Mengelola kelas

3. Absensi kehadiran siswa

4. Menyampaikan tujuan pembelajaran dengan menggunakan model pembelajaran inquiri.

5. Menyajikan materi pelajaran

6. Memberikan kesempatan kepada siswa untuk bertanya

7. Melakukan umpan balik kepada siswa, siswa dibagi menjadi 6 kelompok.
8. Setiap kelompok menempati tempat duduknya secara kelompok

9. Guru menyiapkan wacana tentang materi Dasar Akuntansi

10. Guru memberikan soal yang telah diacak nomornya untuk dikerjakan siswa secara berkelompok, masing-masing kelompok soalnya berbeda.

11. Siswa dalam kelompok masingmasing mengerjakan soal sesuai dengan soal yang ada dalam kelompok

12. Setelah soal dikerjakan maka guru membuat kesimpulan

c) Tahap Observasi

Observasi dilakukan saat proses pembelajaran

d) Tahap Refleksi

Kegiatan pada tahap ini adalah menganalisis hasil kegiatan dari siklus I dan siklus II, dengan melihat dan mengkaji ketercapaian pembelajaran melalaui model pembelajaran sehingga dapat diketahui perbandingan hasil pelaksanaan tindakan siklus I dan siklus II.

\section{PEMBAHASAN}

Penerapan model Inquiri berdampak positif terhadap proses dan hasil 
kegiatan pembelajaran siswa. Dampak positif tersebut adalah siswa lebih memahami materi yang disampaikan guru, siswa selalu berpikir kritis dalam proses pembelajaran, siswa dapat bekerjasama dalam kelompok dan selalu mendiskusikan jika tidak ada yang dimengerti. Selain itu juga hasil belajar siswa dari siklus I dan Siklus II mengalami peningkatan.

Penelitian Tindakan Kelas ini dilaksanakan dalam 2 (dua) siklus, setiap siklus dilaksanakan dalam 4 (empat) tahap, yaitu :

a. Perencanaan tindakan

b. Pelaksanaan tindakan

c. Observasi

d. Refleksi tindakan.

Pada pelaksanaan Siklus I materi yang disampaikan adalah Pengertian jurnal, pengertian buku besar, Penggolongan Akun dan Posting dari jurnal umum ke akun buku besar. Setelah guru menjelaskan dan mempraktekan materi siswa diberikan waktu untuk mempelajari dan diminta untuk menyelesaikan soal praktek dengan teliti dan berpikir secara kritis tidak asalasalan dalam mengerjakan soal dan dapat mempresentasikannya, sehingga siswa dapat menemukan hal-hal baru dalam berpikir secara kritis.
Materi pembelajaran dalam pelaksanaan Siklus II adalah materi tentang penyusunan neraca saldo dan posting dari jurnal khusus ke buku besar, selain itu pelaksanaan siklus II didasarkan atas perbaikan dan kelemahan siklus II. Dengan model pembelajaran inquiri ini siswa menjadi teliti dalam menelaah pelajaran, karena dalam model ini siswa dituntut untuk berpikir secara kritis dan bertanggung jawab serta analitis untuk mencari dan menemukan sendiri jawaban dari suatu masalah yang dipertanyakan. Model pembelajaran sangat mendukung dalam keberhasilan proses pembelajaran, namun lebih dominan peran guru pelajaran karena seorang guru akan selalu membimbing dan memberikan penjelasan materi secara lengkap, memberikan latihan.

Hasil belajar siswa rata-rata sudah mencapai nilai ketuntasan dalam belajar, walaupun ketuntasan belajar siswa ditempuh dalam beberapa siklus. Namun demikian seluruh siswa sudah mendapatkan ketuntasan belajar dengan nilai rata-rata yang berbeda-beda, ada yang di atas ratarata da nada juga yang dibawah rata-rata. 


\section{Grafik 1}

\section{HASIL BELAJAR SISWA}

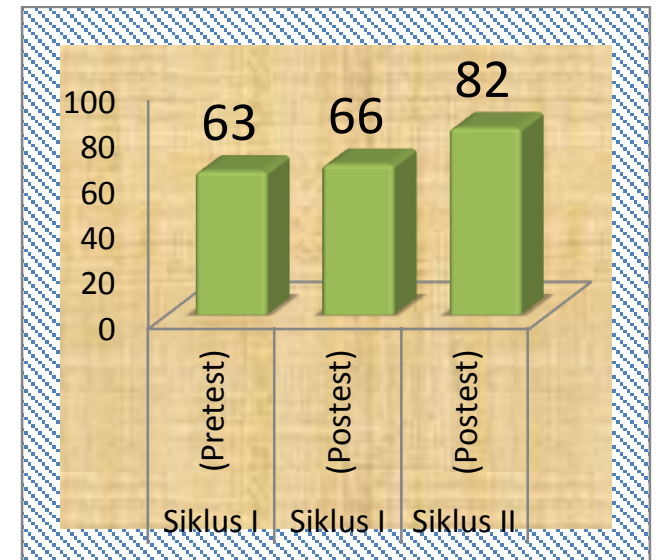

Sumber : Data Primer yang telah diolah

Dari grafik di atas dapat disimpulkan bahwa nilai hasil belajar siswa mengalami peningkatan dari siklus I ke siklus II, dimana pada siklus I pertemuan I nilai rata-rata 63 , mengalami peningkatan pada siklus I pertemuan II nilai rata-rata menjadi 66, dan pada silus II pertemuan II mengalami kenaikan menjadi 82 .

Sedangkan pada hasil penelitian aktivitas siswa yang diamati pada saat pelaksanaan belajar mengajar berlangsung pada siklusnya selalu mengalami peningkatan dan cenderung membaik, setelah mengikuti pelajaran Dasar Akuntansi menggunakan model pembelajaran Inquiri.

Berdasarkan tabel tersebut bahwa data hasil penilaian aktivitas siswa disetiap siklusnya selalu meningkat signifikan ini dikarenakan siswa selalu memperhatikan proses pembelajaran dengan menggunakan model inquiri. Berikut penulis tampilkan grafik aktivitas siswa adalah sebagai berikut :

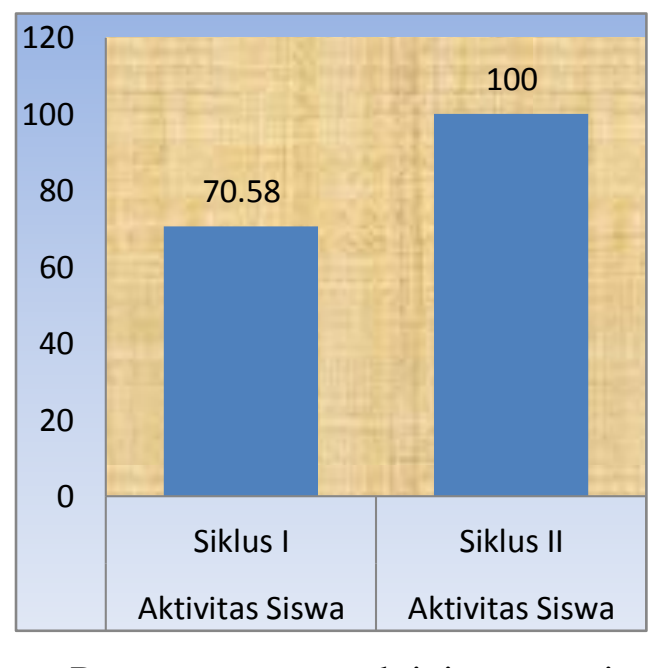

Pengamatan aktivitas siswa dilakukan ketika proses belajar mengajar dimulai sampai proses pembelajaran berakhir. Pengamatan dibantu oleh beberapa observer sebagai penilai aktivitas siswa kemudian dilakukan penskoran terhadap aktivitas siswa berdasarkan kriteria yang telah ditentukan.

Dari grafik diatas bahwa aktivitas siswa setelah mengikuti pelaksanaan pembelajaran dengan menggunakan model pembelajaran Inquiri pada siklus I dan II mengalami peningkatan dimana pada siklus I hanya $70,58 \%$ dan pada siklus II meningkat signifikan mencapai nilai 100 $\%$. Ini menunjukan model inquiri berpengaruh terhadap aktivitas siswa. 
Grafik 2 Penilaian Sikap Kritis Siswa

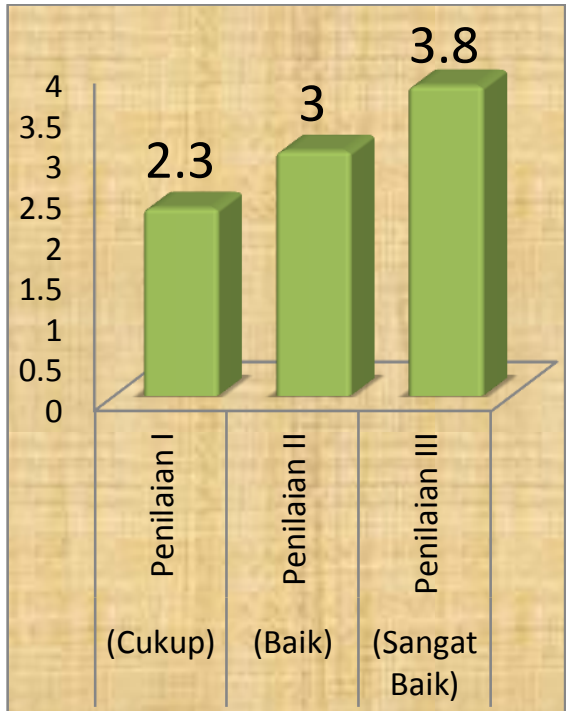

\section{Sumber : Data Primer yang telah diolah}

Pengamatan sikap kritis siswa dilakukan ketika proses belajar mengajar dimulai sampai proses pembelajaran berakhir. Pengamatan dibantu oleh beberapa observer sebagai penilai sikap siswa kemudian dilakukan penskoran terhadap sikap kritis siswa berdasarkan kriteria yang telah ditentukan.

Dari grafik diatas bahwa sikap kritis siswa setelah mengikuti pelaksanaan pembelajaran dengan menggunakan model pembelajaran Inquiri pada penilaian I di siklus I dan II mengalami peningkatan dimana pada siklus I hanya 3,00 (baik) dan pada siklus II meningkat signifikan mencapai nilai 3,8 (sangat baik). Ini menunjukan model inquiri berpengaruh terhadap sikap berpikir kritis siswa.

\section{KESIMPULAN}

Berdasarkan hasil penelitian tindakan kelas dan pembahasan yang telah diuraikan sebelumnya, dapat disimpulkan sebagai berikut :

1. Adanya peningkatan prestasi belajar siswa SMKN 4 Kota Serang dengan Model Pembelajaran Inquiri pada mata pelajaran Dasar Akuntansi, nilai peningkatan belajar siswa dilihat dari hasil penilaian rata-rata belajar siswa dari siklus I memperoleh nilai rata-rata 66 dan siklus II memperoleh nilai ratarata sebesar 82 sehingga ada peningkatan hasil belajar siswa.

2. Pada saat pelaksanaan siklus I \& II guru mengamati terhadap pelaksanaan tindakan yang dilaksanakan oleh peneliti dengan tujuan untuk mengetahui permasalahan dan kemungkinan yang terjadi dengan menggunakan model pembelajaran Inquiri. Sehingga dapat diketahui aktivitas siswa pada siklus I sebesar $30,56 \%$ dan $82 \%$ pada siklus II sebesar $100 \%$. Jadi berdasarkan hasil penelitian diketahui hipotesis penelitian terbukti, artinya bahwa penggunaan model pembelajaran Inquiri dapat meningkatkan hasil belajar siswa. 
3. Sikap berpikir kritis siswa setelah mengikuti pelaksanaan pembelajaran dengan menggunakan model pembelajaran Inquiri pada penilaian I di siklus I mengalami peningkatan dimana pada siklus I hanya 3,00 (baik) dan pada siklus II meningkat signifikan mencapai nilai 3,8 (sangat baik). Ini menunjukan model inquiri berpengaruh terhadap sikap berpikir kritis siswa.

\section{SARAN}

1. Bagi guru, dapat memberikan macammacam model pembelajaran salah satunya adalag model inquiri, sehingga proses pembelajaran yang dilaksanakan dapat merubah pola pikir anak menjadi selalu berpikir kritis dan analitis untuk mencari dan menemukan sendiri jawaban daari suatu permasalahan yang ditemui atau dipertanyakan sehingga menimbulkan semangat dan percaya diri

2. Bagi siswa, diharapkan selalu komunikatif dan selalu percaya diri agar selalu mengembangkan kemampuan intelektual sebagai bagian dari proses pengembangan mental.

\section{DAFTAR PUSTAKA}

Arikunto, Suharsimi DKK. (2015).

Penelitian Tindakan Kelas. Bumi Akara: Jakarta
Arikunto, Suharsimi. (2012). Dasar-dasar Evaluasi Pendidikan. Bumi Aksara. Jakarta.

Astuti, Sari Dewi (2017) Pengantar Akuntansi. Mediatama: Surakarta

Desmita. (2010). Psikologi Perkembangan. PT. Bandung :Remaja Rosdakarya

Djamarah, SB \& A. Zaini. (2002). Strategi belajar mengajar. Rhineka Cipta.:Jakarta : xi +252 hlm.

Hafsyah, S. (2012). Penerapan Model Inkuiri Terstruktur Dengan Media Virtual-Lab Pada Pembelajaran Akuntansi Di SMP. Jurnal Pembelajaran Fisika: ISSN 23019794. Vol.1 No. 2: 158-164.

Harti, Dwi. (2017). Dasar Akuntansi untuk $S M K$. Erlangga: Jakarta.

Huda, Miftahul. (2014). Model-model Pembelajaran dan Pengajaran. Pustaka Pelajar: Yogyakata.

Majid, Abdul (2016). Strategi Pembelajaran. Remaja Rosdakarya: Bandung

Mustachfidoh. (2013). Pengaruh Model Pembelajaran Inkuiri Terhadap Prestasi Belajar Akuntansi Ditinjau Dari Inteligensi Siswa SMA Negeri 1 Srono. E-Journal Program Pascasarjana Universitas Pendidikan Ganesha Program Studi Pendidikan Sains. Vol. 3 No. 1: 23-32.

Purwanto. (2016). Evaluasi Hasil Belajar. Pustaka Pelajar: Yogyakarta

Sagala, Syaiful. (2011). Konsep dan Makna Pembelajaran. Bandung: Alfabeta

Sanjaya, Wina.(2016). Strategi Pembelajaran Berorientasi Standar 
Proses Pendidikan. Jakarta:

Kencana Prenada Media Grup

Sudaryono, (2015). Metode Penelitian

Pendidikan. Prenamedia Group:

Jakarta

Surya, Hendra. (2011). Strategi Jitu

Mencapai Kesuksesan Belajar.

Jakarta: Gramedia.

Trianto. (2007). Model-model

Pembelajaran Inovatif Berorientasi

Konstruktivistik. Jakarta: Prestasi

Pustaka 